\title{
Deltaic Lateritic Soil in 1:5:11 Mix Design for Producing Controlled Low-Strength Material (CLSM) for Pavement Backfill
}

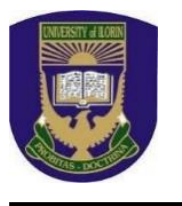

\author{
J. A. Oke \\ Department of Civil \& Environmental Engineering, University of Lagos, Akoka, Nigeria.
}

ABSTRACT: Deltaic lateritic soil obtained from Emohua in Rivers State, Nigeria was studied to ascertain its suitability as a substitute to sand in concrete for producing controlled low-strength material (CLSM). Cement, coarse aggregate, as well as lateritic soil which replaced sand was combined in ratio 1:5:11 to produce lateritic concrete using varying water-cement $(\mathrm{w} / \mathrm{c})$ ratios at varying curing durations. Variation in the $\mathrm{w} / \mathrm{c}$ ratios ranging from 0.2 to 0.5 at 0.1 intervals and the curing periods which varied between 7, 14 and 28 days were examined. As with the case with conventional concrete, strength development, as well as cement hydration took place after casting over the curing periods. Recent applications using CLSM recommends that a compressive strength of $8.3 \mathrm{~N} / \mathrm{mm}^{2}$ or less is required for materials used as conventional compacted backfill soil or structural fillings. In a situation where future excavation is envisioned, it is recommended that the maximum long-term compressive strength of CLSM should generally have an upper limit of $2.1 \mathrm{~N} / \mathrm{mm}^{2}$ for compacted backfill material hence, the lateritic concrete produced in this study using the 1:5:11 mix design at $0.2 \mathrm{w} / \mathrm{c}$ ratio, cured for 28 days which gave strength of $5.3 \mathrm{~N} / \mathrm{mm}^{2}$ can be used as CLSM which primarily, can be utilized as a substitute for compacted backfill to sub-base and/or subgrade of flexible pavements. Where necessary, super plasticizer can be introduced to increase flowability of the lateritic concrete.

KEYWORDS: Lateritic soil, controlled low-strength material, compressive strength, water-cement ratio, curing periods, cement hydration.

[Received Oct. 15, 2020, Revised July 5, 2021, Accepted July 15, 2021]

Print ISSN: 0189-9546 | Online ISSN: 2437-2110

\section{INTRODUCTION}

Research on the construction of cheaper and more durable roads using indigenous construction materials is beginning to receive more attention in recent times (Oke et al, 2020). In addition, sand has traditionally been the conventionally used fine aggregate in the production of concrete however, it is dredged and transported from relatively distant places at high costs, which contributes to an increase in the overall cost of producing concrete (Brahmaji et al, 2017).

A major challenge experienced in the building sector in underdeveloped and developing countries is the premium placed on road construction because of high costs experienced during stabilization using conventional road construction additives like lime, cement etc. (Bello et al, 2015; Oke and Olowoyo, 2019). The frequent increase in prices of road construction materials across Nigeria has been much aggravated by the depreciating value of the Naira against other currencies thereby resulting in the need to research into the production and use of local materials as cheaper and readily affordable alternatives. One of such local material that is receiving attention is the lateritic group of weathered soil materials.

For ages in Nigeria, soils classified as lateritic has continued to be a significant construction material for the construction of pavements and buildings (Onyelowe et al,
2019; Etim et al, 2020; Obianyo et al, 2020). For pavement construction, it is usually utilized as a compacted fill material and/or a subbase construction material while for low-cost residential buildings in rural areas, it is used to produce lateritic blocks. In some other cases, it is used to produce face-brick used to beautify houses in urban areas. The main reason for its versatile use in construction is because it is readily available in Nigeria and tropical Africa (Oke et al, 2020).

This research is a contribution to the study of deltaic lateritic soil properties with the view to relating its properties such as moisture content, grading, consistency limits, and shrinkage to the performance characteristics and compressive strength of the lateritic concrete produced using 1:5:11 mix ratio with variations in w/c ratio and curing periods for producing CLSM for use as pavement backfill.

\section{A. Lateritic Soil}

Various definitions have been proposed for lateritic soils based on its chemical composition, hardening properties and morphological characteristics. They have been described as ferruginous vesicular, unstratified and porous material with yellow ochres due to high iron contents (Gidigasu, 1976; Mahalinga-Iyer and Williams, 1991; Ko, 2014; Nnochiri and Aderinlewo, 2016). However, a simplified yet precise description of its genesis was provided which elucidates that as a result of rainfall in excess of evaporation which occur in 
tropical humid climatic conditions, a steady infiltration of rainwater as well as storm runoff downward into the earthsurface occurs as such, a process that effects a constant and uninterrupted elimination of dissolved salts from the weathered soil through a process known as leaching takes place (Giorgis et al, 2014; Ko, 2014; Debbarma and Debnat, 2021). This explanation further showed that complex aluminium silicates were broken down rapidly in comparison to other compounds at locations where organic contents were low in the soil hence; there were tendencies of removal of silicates leaving behind iron oxides and clay elements which are termed lateritic soils. In general, lateritic soils are seen as highly weathered materials having superabundant secondary oxides of Aluminium and/or Iron of which these oxides are formed in hot and wet tropical areas (Gidigasu, 1976; Ko, 2014; Giorgis et al, 2014; Debbarma and Debnat, 2021). They usually vary in shades such as pink, red or brown due to the iron oxides in various states of hydration however, they are generally bright coloured.

\section{B. Controlled Low-Strength Material (CLSM)}

CLSM is described as a material that is cementitious, which levels and compacts itself and can essentially be used for backfilling in the place of conventional compacted backfill soil and/or structural fillings (Howard and Hitch, 1998; Lee et al, 2013; Ling et al, 2018; Kaliyavaradhan et al, 2019). CLSM usually have crushing strengths values of $8.3 \mathrm{~N} / \mathrm{mm}^{2}$ or lower at 28 days (ACI 229R-94:1994; Howard and Hitch, 1998; ACI PRC-229-13:2013; Lee et al, 2013; Do and Kim, 2016; Ling et al, 2018; Kaliyavaradhan et al, 2019). Recent applications of CLSM require that compressive strengths with upper limit of $2.1 \mathrm{~N} / \mathrm{mm}^{2}$ is recommended to allow for future excavation of the put-in-place CLSM using mechanized excavating equipment however, using conventional hand-digging equipment for future excavations, CLSM having compressive strengths of $0.34-0.70 \mathrm{~N} / \mathrm{mm}^{2}$ are advised (ACI 229R94:1994; ACI PRC-229-13:2013; Do and Kim, 2016). Diverse intrinsic benefits of utilizing CLSM in lieu of compacted fill include savings on equipment and labour cost as a result in its self-levelling properties, speedy construction, and the ease of placing them in constricted spaces (ACI 229R-99:1999; ACI PRC-229-13:2013; Do and Kim, 2016). Some main applications of CLSM include backfills to pavement bases (subbase and subgrade), structural fills to road bases, trench backfilling, backfill to bridge abutments, backfill to building excavations, slope stabilization, etc. (ACI 229R-94:1994; ACI PRC-229-13:2013) (see Figure 1.).

Researchers have carried out tests on the production of CLSM using recycled materials such as fly ash, scrap tire rubber, recycled glass, acid mine drainage (AMD) sludge etc. as well as using industrial by-products with a view to reduce the amount of cement used to produce the concrete thereby leading to a reduction in its cost of production ( $\mathrm{Gabr}$ and Bowders, 2002; Do and Kim, 2016; Ling et al, 2018; Kaliyavaradhan et al, 2019). Depending on project requirements, soil or recycle/waste materials that are either locally available, non-standard, more economical or byproducts can be used in the production of CLSM (ACI 229R94:1994; ACI PRC-229-13:2013; Kaliyavaradhan et al, 2019).

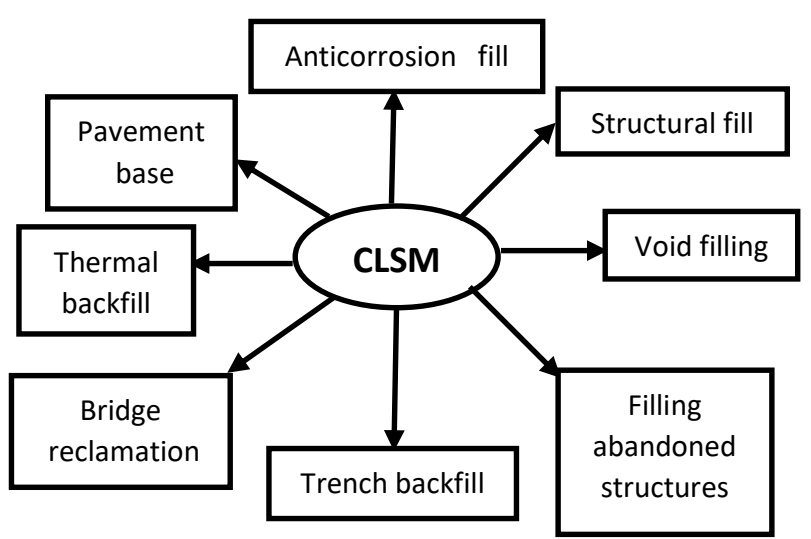

Figure 1: Some main applications of CLSM (Source: Ling et al, 2018).

It should however be noted that the type, amount of materials and method used in the production of CLSM should be designed such that the required characteristics for its desired application is achieved (Halmen, 2005; Qian et al, 2015; Kaliyavaradhan et al, 2019) hence, this study considered using the 1:5:11 mix design as a means of producing lateritic CLSM by volume batching using lateritic soil instead of the conventional sand since lateritic soil is abundant in the Deltaic part of Nigeria and also cheaper when compared to sand thereby resulting in the production of cheaper lateritic concrete.

\section{MATERIALS AND METHODS}

\section{A. Materials}

Lateritic fine aggregate utilized in this research was secured from an active borrow-pit located at Emohua in Rivers State, Nigeria having locations of $4^{\circ} 53^{\prime} 2^{\prime \prime}$ "North and $6^{\circ} 51^{\prime}$ 39" East (Figure 2). The Emohua area is located under a climatic province of tropical rain forest and falls within the zone underlain by coastal plain sand and alluvium sedimentary deposits. The lateritic soil was obtained through disturbed sampling at depths between $1.5 \mathrm{~m}$ and $2.5 \mathrm{~m}$ beneath the ground surface in order to avoid organic topsoil. A visual examination of the lateritic soil sample revealed that it is reddish brown when wet and light brown in the dry state with patches of yellowish inclusions. Air-drying of the lateritic soil was carried out for approximately 14 days in order to gain on its potentials to aggregate when exposed (BS 1377:1990-Part 2; Omotosho and Akinmusuru, 1992).

Coarse aggregate used in this study was obtained from a quarry along Aba-Port Harcourt expressway having sizes that were retained on 3/16 BS sieve (ACI 301-20: 2020). The coarse aggregate was washed to remove impurities and organic material thereafter, it was air dried. Portland Limestone cement used in the study was obtained from the open market. Physical checks carried out on the cement included checks on the sealing of the bags, the fineness of the cement to ascertain if the cement powder had caked as well as where and how the bags of cement were stored. Portable water from the University 


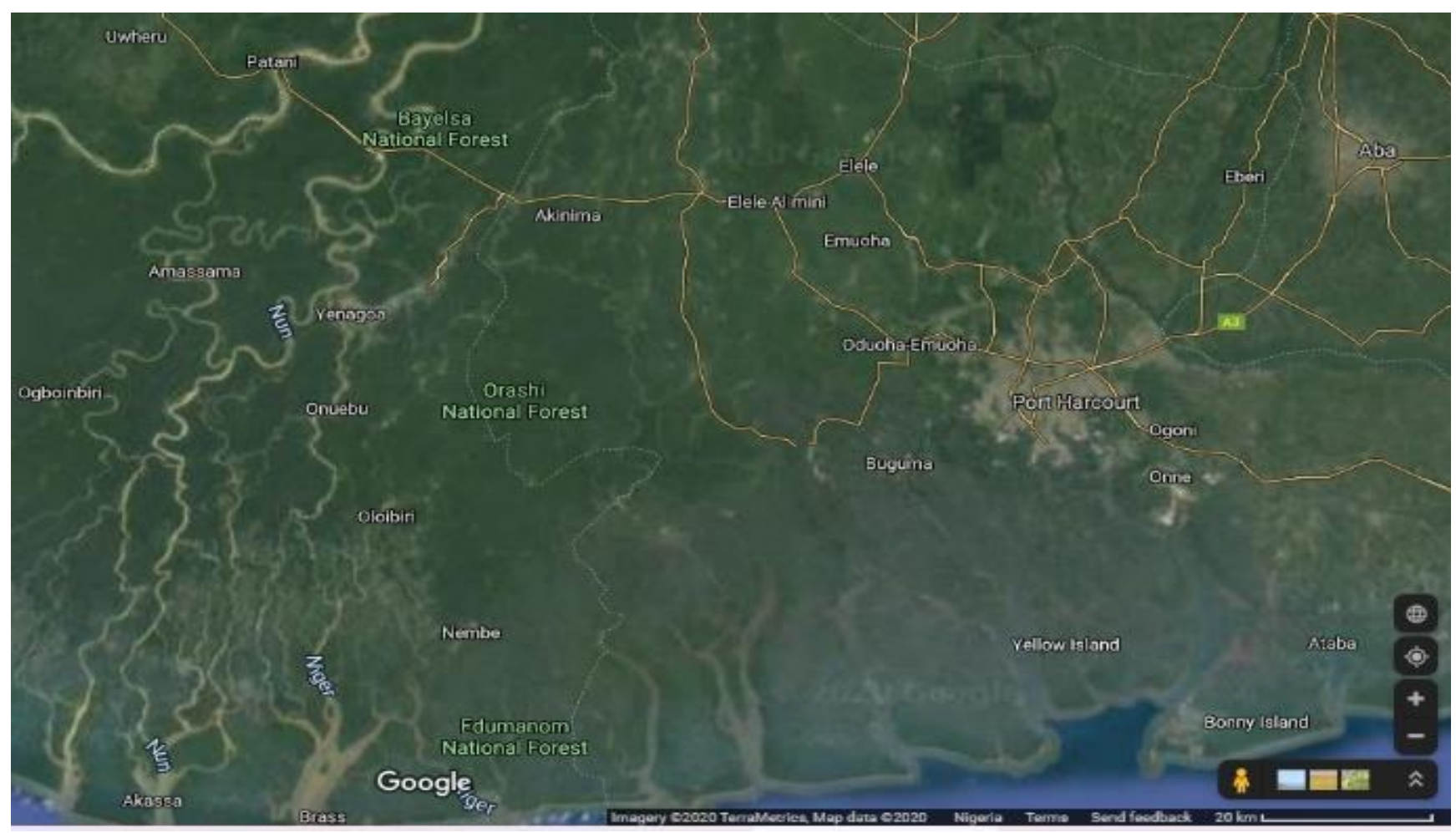

Figure 2: Map showing Emuoha, the location of sample borrow-pit.

of Port Harcourt Soil \& Geotechnical Engineering Laboratory was used for the experiments.

\section{B. Methods}

Moisture content, sieve analysis, consistency limit, linear shrinkage, specific gravity and classification tests were carried out to ascertain the physical properties of the lateritic soil sample.

\section{1.) Determination of moisture content}

The soil sample obtained from the borrow pit was immediately tied in a polythene bag in order to prevent any moisture loss and taken to the laboratory for moisture content determination. The moisture content determination was carried out by the oven-drying method which is regarded as a standard laboratory practice specified by BS Code 1377:1990-Part 2 .

Three different moisture containers with their lids were cleaned properly and then weighed $\left(W_{l}\right)$ approximately to $0.1 \mathrm{~g}$. The samples in their fresh state were crumbled into smaller pieces and deposited in the moisture containers then weighed $\left(W_{2}\right)$ with the lids. These were placed in the oven for 24 hours at temperatures ranging between $105-110{ }^{\circ} \mathrm{C}$ to a constant weight after which they were brought out and allowed to cool before weighing with their lids as $W_{3}$. The natural moisture content $(w)$ was calculated as the average of the three oven dried samples using Eq. (1).

$\frac{W_{2}-W_{3}}{W_{3}-W_{1}} \times 100 \%=\mathrm{w}(\%)$
Accordingly,

$W_{l}=$ the weight of the empty moisture container with lid

$W_{2}=$ the weight of the moisture container with lid + fresh soil $W_{3}=$ the weight of the moisture container with lid + ovendried soil

$w=$ natural moisture content

\section{2.) Gradation test}

The gradation test was conducted in line with codes (BS 1377:1990-Part 2; BS 1924: 1990) and research (Neville and Brooks, 2002) using the dry sieve method. $500 \mathrm{~g}$ of air-dried lateritic soil sample was weighed and sieved through 8 different sieve sizes $(2.360,1.180,0.600,0.425,0.300,0.212$, 0.150 and $0.075 \mathrm{~mm}$ ) using the mechanical sieve shaker. Hydrometer test was carried out on the portion of the sample that passed through the $0.075 \mathrm{~mm}$ aperture sieve to establish the silt and clay composition.

The percentage of soil that passed through the sieves as well as the cumulative percentage of that which was retained on each sieve in grams was calculated using Eq. 2. (BS 1377:1990-Part 2).

$W_{4}=\frac{W_{2}-W_{1}}{W_{3}} \times 100(\%)$

Accordingly,

$W_{1}=$ the weight of the sieve

$W_{2}=$ the weight of sieve and the soil

$W_{3}=$ the total weight of the soil

$W_{4}=$ amount retained on each sieve

Percentage passing through $=100-$ cumulative percentage of the soil to be retained 


\section{3.) Consistency limits}

The consistency limit tests were performed in accordance to BS 1377:1990-Part 2 to ascertain their liquid limit (LL), plastic limit (PL) as well as plasticity index (PI).

For LL determination, $100 \mathrm{~g}$ of air-dried sample already passed through $0.425 \mathrm{~mm}$ aperture sieve was mixed thoroughly with water on a flat glass plate to obtain a homogenous mixture. A portion of this homogenous mixture was put in a standard Casagrande apparatus, smoothened off parallel to the bottom of the cup and split into two by creating a channel using the grooving tool through the middle of the hinge. The cup was then lifted and dropped intermittently by turning the crank until the channel that was created came together at the base. A record of the number of blows which caused the closure was taken thereafter, a part of soil paste was used for moisture content determination.

A part of the homogenous paste that was used in determining the LL test was retained and used to determine the PL. The mixture was rolled with the palms into balls to a point that they were sufficiently dehydrated. The balls were then split into 4 equal parts. Every part was rolled into a strand using the fore finger and thumb. The strand was further rolled this time on the surface of a glass using the tip of the fingers in a forward and backward movement until the strand at approximately $3 \mathrm{~mm}$ crumbled. The first crumble point was the PL thereafter, the crumbled soil sample was placed in moisture containers for moisture content determination. PI was determined using LL-PL.

\section{4.) Preparation of $150 \mathrm{~mm}$ by $150 \mathrm{~mm}$ by $150 \mathrm{~mm}$ lateritic concrete cubes}

In this experiment, the cement, coarse as well as fine aggregate were batched by volume using the 1:5:11 mix design. For the production of CLSM, the type and amount of materials as well as the method I used was designed such that the required characteristics for its desired application would be achieved (Halmen, 2005; Qian et al, 2015; Kaliyavaradhan et $a l, 2019)$. In addition, the Engineer gives the specifications for the mixture with the required characteristics for the desired application to be obtained (ACI 229R-94:1994; Howard and Hitch, 1998). In this case, batching by volume was carried out to ascertain if a minimum strength of $2.8 \mathrm{~N} / \mathrm{mm}^{2}$ for lateritic CLSM for the purpose of backfill to pavements would be achieved. The proportions were measured using a gauge box of known volume.

The combined volumes of cement, coarse and fine aggregate were mixed thoroughly and then divided into four equal parts. To the first part of the mix, $0.2 \mathrm{w} / \mathrm{c}$ ratio was added and mixed then filled into formwork measuring $150 \mathrm{~mm} \mathrm{x}$ $150 \mathrm{~mm} \times 150 \mathrm{~mm}$ which had earlier been lubricated to enable the cube come out easily without cracks. The prepared concrete was used to fill the mould in 2 layers, each of the layers measuring approximately $75 \mathrm{~mm}$ thick. Each layer was rammed 25 strokes with a steel bar of $16 \mathrm{~mm}$ diameter and $375 \mathrm{~mm}$ in length. Lastly, levelling off of the compacted concrete was carried out and was allowed to sit for 24 hours prior to de-moulding. They were weighed and thereafter stored in a tank filled with water.
To the second, third and fourth parts of the mix, 0.3, 0.4 and $0.5 \mathrm{w} / \mathrm{c}$ ratios were added and the process of compacting, levelling-off, de-moulding and weighing was repeated. The different $w / c$ ratios were shown on the top of each cube. A total of 36 lateritic concrete cubes were produced i.e., each w/c ratio content had three samples and the average was taken for each sample.

\section{5.) Determination of compressive strength}

The compressive strength which refers to the peak stress any sample can withstand when tested was conducted on the cube specimens for every water cement ratio considered $(0.2$, $0.3,0.4$ and 0.5 ) which corresponded to their curing periods of 7,14 as well as 28 days respectively. Tests on the cured cubes were then carried out on days 7,14 and 28 respectively using the compression test machine.

The testing procedures were carried out in line with codes (BS 1881-116: 1983; ACI 301-20:2020). The cured samples were wiped-off from grits and placed at the centre with the required load applied constantly till the sample was crushed and the maximum load attained was recorded. This was then used to calculate the compressive strength that is, the ratio of the maximum load to the cross-sectional area of the tested sample which is expressed in $\mathrm{N} / \mathrm{mm}^{2}$. Three samples each were utilized for each test and then, the average results were picked to be the compressive strength.

The formula for determining the compressive strength is:

Compressive Strength $\left(\mathrm{N} / \mathrm{mm}^{2}\right)=\frac{\operatorname{Load}(\mathrm{N})}{\operatorname{Area}\left(\mathrm{mm}^{2}\right)}$

Accordingly,

Load $=$ load documented from the testing machine $(\mathrm{N})$

Area $=L^{2}=$ total surface area of the cube $\left(\mathrm{mm}^{2}\right)$

$L=$ length of the cube (mm)

\section{RESULTS AND DISCUSSION}

Table 1 shows a summary of natural properties of the lateritic soil. The sieve analysis result plotted on Figure 3 shows that the soil sample has a coefficient of curvature $(\mathrm{Cc})$ value of 1.1 and coefficient of uniformity $(\mathrm{Cu})$ value of 17.3. This implies that the soil used in this study is well graded (BS 1377: 1990-Part 2).

Results of the compressive stresses plotted against their respective w/c ratios are presented in Figures 4-6. It should be noted that the overall quality of the concrete is determined by its compressive strength hence, it is a very important factor to be determined in concrete production. It could be deduced from the plots that compressive strength decreased with an increase in the w/c ratio which results from the fact that, when a concrete mix is over hydrated, it could lead to easy separation of particles at low density which implies low strength (ACI 301-20: 2020). $0.2 \mathrm{w} / \mathrm{c}$ ratio in this study was the most effective for the 1:5:11 lateritic concrete mix which is recommended for producing controlled low-strength material (CLSM) as a suitable replacement for compacted backfill to pavements (Howard and Hitch 1998; ACI 229R-94:1994; Ling et al., 2018). 
Table 1 Natural properties of the lateritic soil.

\begin{tabular}{ll}
\hline Property & Quantity \\
\hline Natural Moisture Content, \% & 25.1 \\
Percentage Passing No. 200 sieve & 35.0 \\
(75 $\mu$ m aperture) & \\
Liquid Limit, \% & 36.0 \\
Plastic Limit, \% & 25.0 \\
Plasticity Index, \% & 11.0 \\
Linear Shrinkage, \% & 8.6 \\
Specific Gravity & 2.51 \\
AASHTO Classification & A-2-6 (4) \\
USCS & CL \\
Colour & Reddish brown \\
Coefficient of curvature $(\mathrm{Cc})$ & 1.1 \\
Coefficient of uniformity $(\mathrm{Cu})$ & 17.3 \\
Material & Lateritic clayey \\
& sand \\
Grain Distribution \% & Sand \\
& Silt \\
& Clay \\
\hline
\end{tabular}

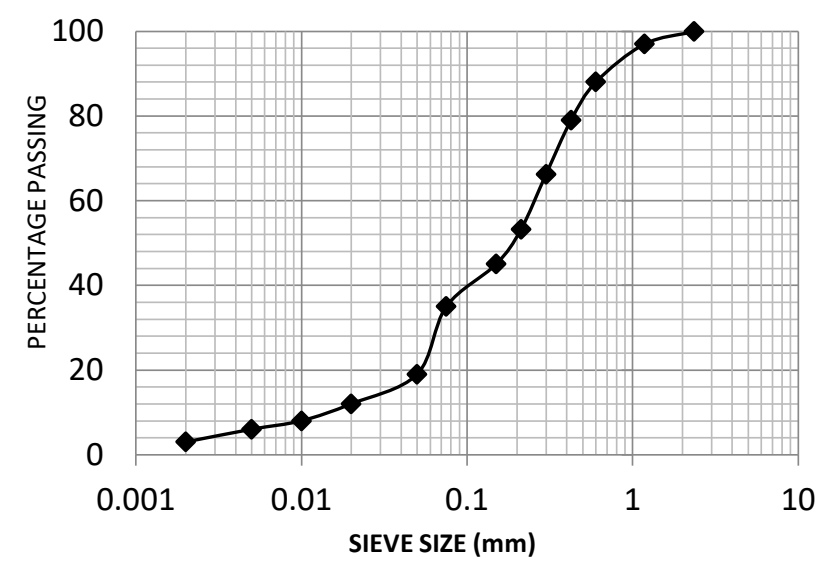

Figure 3: Gradation curve of lateritic soil.

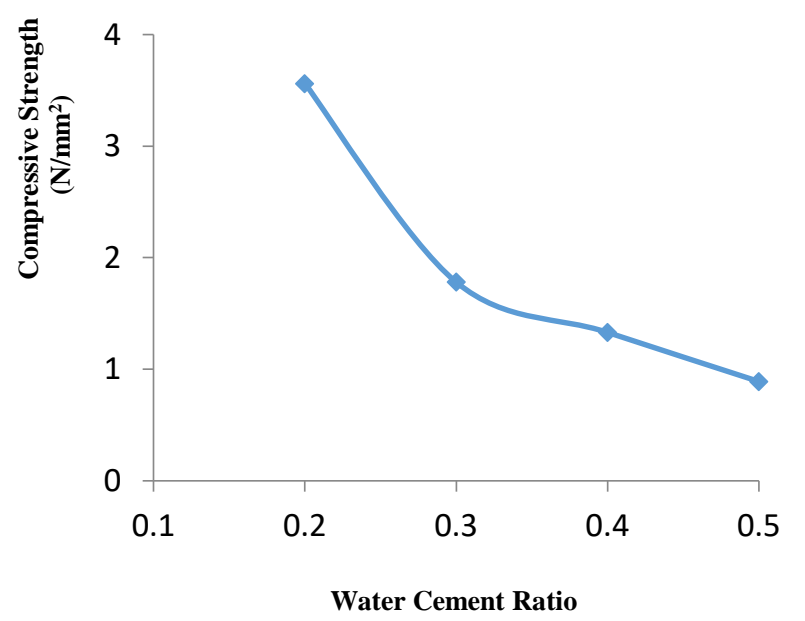

Figure 4: Effects of water cement ratio on the compressive strength -7 days.

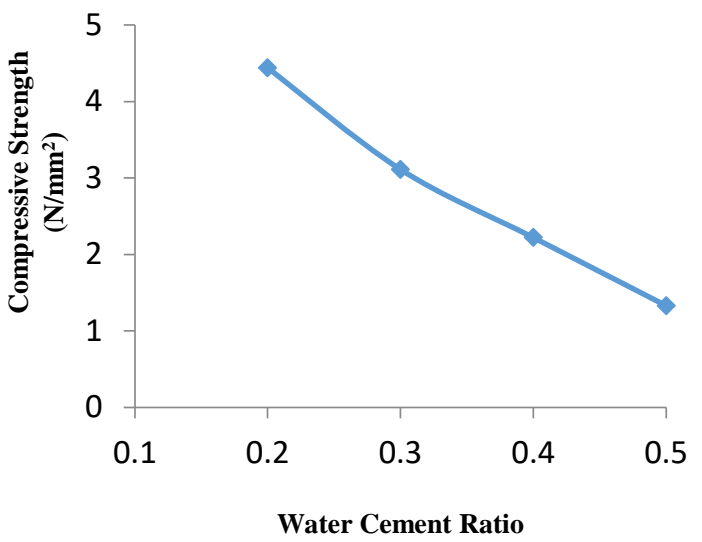

Figure 5: Effects of water cement ratio on the compressive strength - 14 days

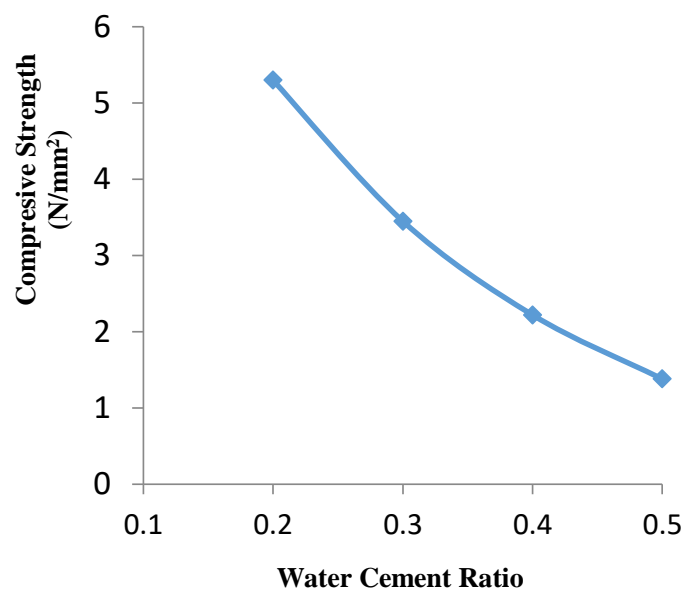

Figure 6: Effects of w/c ratio on the compressive strength - 28 days.

The general increase in strength recorded in this study was as a result of cement hydration which mainly was a result of the formations of dissimilar compounds like calcium aluminate hydrates $(\mathrm{CAH})$ as well as calcium silicates hydrates $(\mathrm{CSH})$ contained in the cement in addition to the micro fabric modifications, which accounts for strength gain (Negi et al, 2013; Oke and Osinubi, 2019; Oke and Osinubi, 2020).

As with conventional concrete, over $80 \%$ of compressive strength at 28 days are usually developed by the $14^{\text {th }}$ day, while over $60 \%$ strength are developed by the $7^{\text {th }}$ day (BS 1881116:1983; ACI 301-20:2020). Results of 3.6, 4.4 and 5.3 $\mathrm{N} / \mathrm{mm}^{2}$ were obtained in this study as the compressive strengths developed by the $7^{\text {th }}, 14^{\text {th }}$ and $28^{\text {th }}$ day considering $0.2 \mathrm{w} / \mathrm{c}$ ratio respectively; this is in agreement with the rate of strength development in concrete (BS 1881-116:1983; ACI 301-20:2020).

\section{CONCLUSION}

Lateritic soil from Emohua classified as CL and A-2-6 (4) using the USCS and AASHTO classifications respectively was subjected to tests to determine its natural properties, ascertain its suitability as a substitute to sand in concrete and determine its compressive strength for producing CLSM. CLSM concrete 
which is characterised by its low strength usually has crushing strengths values of $8.3 \mathrm{~N} / \mathrm{mm}^{2}$ or lower hence, is considered unsuitable for supporting bridges, buildings, or other engineering structures however, it can be used as a backfill material (Ling et al, 2018). In a situation where future excavation is envisioned, it is recommended that the maximum long-term compressive strength of CLSM should generally have an upper limit of $2.1 \mathrm{~N} / \mathrm{mm}^{2}$ for compacted backfill material (ACI 229R-94:1994; ACI PRC-229-13:2013; Do and Kim, 2016; Ling et al, 2018; Kaliyavaradhan et al, 2019) hence, the following conclusions can be made:

a) The lateritic soil in this study is well graded hence it is suitable as a fine aggregate for producing concrete.

b) The lateritic concrete produced using the 1:5:11 mix design at 0.2 and $0.3 \mathrm{w} / \mathrm{c}$ ratios, cured for 28 days which gave strengths of 5.3 and $3.5 \mathrm{~N} / \mathrm{mm}^{2}$ respectively can be used as CLSM which primarily, can be utilized as a substitute for compacted backfill soil to sub-base and/or subgrade of flexible pavements. This is in line with recommended 28-day compressive strengths which should be within $2.8-8.3 \mathrm{~N} / \mathrm{mm}^{2}$ (Ling et al, 2018). Where necessary, super plasticizer can be introduced to increase flowability of the lateritic concrete.

c) The lateritic concrete produced having lower compressive strengths of 2.2 and $1.4 \mathrm{~N} / \mathrm{mm}^{2}$ obtained at 28 days curing using 0.4 and $0.5 \mathrm{w} / \mathrm{c}$ ratios respectively can be used as CLSM for backfill to roadway trenches, storm-drainage pipelines and conduit beddings. This is in line with recommended 28 day compressive strengths being $\leq 2.1 \mathrm{~N} / \mathrm{mm}^{2}$ (Ling $e t$ $a l, 2018)$.

In order to produce lateritic concrete with improved strength as a structural concrete, it is recommended that further studies should be carried out using a different mix design and the results compared to that which has already been obtained in this study.

\section{ACKNOWLEDGEMENTS}

The author wishes to express her profound appreciation to the supervisor of this work, Late Engr. Dr. P. O. Omotosho for his expert advice, encouragement and for sharing his pearls of wisdom during the course of this research. She also remains immensely grateful to the members of staff at the Soil \& Geotechnical Engineering Laboratory, University of Port Harcourt, Choba, for their support during experimentation of the work.

\section{REFERENCES}

American Concrete Institute (ACI) 229R-94 (1994). Controlled Low-Strength Material (CLSM), 16 (7): 55-64.

American Concrete Institute (ACI) 229R-99 (1999). Controlled Low-Strength Material (CLSM), Farmington Hill.

American Concrete Institute (ACI) PRC-229-13 (2013). Report on Controlled Low-Strength Materials, ACI Committee, Volume 229, Farmington Hill, MI.

American Concrete Institute (ACI) 301-20 (2020). Specifications for Concrete Construction. ISBN: 978-1-64195107-4: 19-24.
BS 1881-116 (1983). Methods of Testing Concrete. Method for Determination of Compressive Strength of Concrete Cubes (AMD 6097) (AMD 6720).

BS 1377-2 (1990). Methods of Test for Soils for Civil Engineering Purposes-Part 2: Classification Tests.

BS 1924-2 (1990). Stabilized Materials for Civil Engineering Purposes. Part 1: General Requirements, Sampling, Sample Preparation and Tests on Materials before Stabilization.

Bello, A. A.; J. A. Ige and H. Ayodele. (2015). Stabilization of Lateritic Soil with Cassava Peel Ash. British Journal of Applied Science and Technology, 7 (6): 642-650.

Brahmaji, K. N.; B. Ganesh; G. V. L. N. Murthy and K. Chandrika. (2017). An Experimental Analysis on Usage Potential of Lateritic Soil as Part/Full Replacement for Fine Aggregates in Concrete. International Journal of Current Engineering and Scientific Research, 4 (2): 11-17.

Debbarma, J. and Debnat, J. (2021). Assessment on the Impact of the Tripura Earthquake (January 3, $2017 \mathrm{M}_{\mathrm{w}}$ 5.6) in Northeast India. Journal of Geographical Institute Jovan Cvijic SASA, 71(1): 1-13.

Do, T. M. and Kim, Y. (2016). Engineering Properties of Controlled Low Strength Material (CLSM) Incorporating Red Mud. International Journal of Geo-Engineering, 7(7): 1-17 https://doi.org/10.1186/s40703-016-0022-y.

Etim, R. K.; I. C. Attah and P. Yohanna. (2020). Experimental Study on Potential of Oyster Shell Ash in Structural Strength Improvement of Lateritic Soil for Road Construction. International Journal of Pavement Research and Technology. Chinese Society of Pavement Engineering, 13(4): 341-351, https://doi.org/ 10.1007/s42947-020-0290-y.

Gabr, M. A. and Bowders, J. J. (2002). Controlled LowStrength Material using Fly Ash and AMD Sludge. Journal of Hazardous Materials 76 (2-3):251-263.

Gidigasu, M. D. (1976). Laterite Soil Engineering. Paedogenesis and Engineering Principles. Developments in Geotechnical Engineering Volume 9. Elsevier Scientific Publishing Company, Amsterdam, The Netherlands.

Giorgis, I.; S. Bonetto; R. Giustetto; A. Lawane; A. Pantet; P. Rossetti; T. Jean-Hugues and R. Vinai. (2014). The Lateritic Profile of Balkouin, Burkina Faso: Geochemistry, Mineralogy and Genesis, Journal of African Earth Sciences, 90(2014):31-48. https://doi.org/10.1016/j.jafrearsci.2013.11.006.

Halmen, C. (2005). Physiochemical Characteristics of Controlled Low Strength Materials Influencing the Electrochemical Performance and Service Life of Metallic Materials. Doctoral Dissertation, Texas A\&M University. Available online at: https://hdl.handle.net/1969.1/4840.

Howard, A. K. and Hitch, J. L. (1998). The Design and Application of Controlled Low-Strength Materials (Flowable Fill). ASTM, STP 1331, Special Technical Publication. West Conshohocken, PA.

Kaliyavaradhan, S. K.; T. C. Ling; M. Z. Guo and K. H. Mo. (2019). Waste Resources Recycling in Controlled Low-Strength Material (CLSM): A Critical Review on Plastic Properties. Journal of Environmental Management, 241(1):383-396. 
Ko, T. H. (2014). Nature and Properties of Lateritic Soils Derived from Different Parent Materials in Taiwan. The Scientific World Journal, 2014(247194):1-4. https://doi.org/10.1155/2014/247194

Lee, N.K.; H. K. Kim; I. S. Park and H. K. Lee. (2013). Alkali-activated, Cementless, Controlled Low-Strength Materials (CLSM) Utilizing Industrial By-Products, Construction and Building Materials, 49(2013):738-746. https://doi.org/10.1016/j.conbuildmat.2013.09.002.

Ling, T. C.; S. K. Kaliyavaradhan, and C. S. Poon. (2018). Global Perspective on Application of Controlled LowStrength Material (CLSM) for Trench Backfilling - An Overview. Construction and Building Materials, 158(2018):535-548.

https://doi.org/10.1016/j.conbuildmat.2017.10.050.

Mahalinga-Iyer, U. and Williams, D. J. (1991). Engineering Properties of a Lateritic Soil Profile, Engineering Geology, 31(1):45-58. https://doi.org/10.1016/00137952(91)90056-Q.

Negi, A. S.; M. Faizan; D. P. Siddharth and R. Singh. (2013). Soil Stabilization using Lime. International Journal of Innovative Research in Science, Engineering and Technology, 2 (2): 448-453.

Neville, A. M. and Brooks, J. J. (2002). Concrete Technology, 2nd Edition, Longman Publishers, London.

Nnochiri, E. S. and Aderinlewo, O. O. (2016). Geotechnical Properties of Lateritic Soil Stabilized with Banana Leaves Ash. Journal of Engineering and Technology, 1(1): 116-119.

Obianyo, I. I.; E. N. Anosike-Francis; G. O. Ihekweme; Y. Geng; R. Jin; A. P. Onwualu, and A. B. O. Soboyejo. (2020). Multivariate Regression Models for Predicting the Compressive Strength of Bone Ash Stabilized Lateritic Soil for Sustainable Building. Construction and Building Materials,
263(2020):1-9.

https://doi.org/10.1016/j.conbuildmat.2020.120677.

Oke, J. A. and Olowoyo, M. K. (2019). Stabilization of Laterite Soil with Eggshell Powder and Sodium Silicate used as Fill Material in Road Construction. Arid Zone Journal of Engineering, Technology and Environment, 15 (3): 586-597.

Oke, J. A. and Osinubi, K. J. (2019). Oil Palm Empty Fruit Bunch Ash as a Sustainable Stabilizer for Laterite Subbase of Highway Pavements. Paper presented at International Conference on Sustainable Infrastructural Development (ICSID2019), Ota, Nigeria, 1-11.

Oke, J. A.; N. O. Obaji and K. J. Osinubi. (2020). Oil Palm Empty Fruit Bunch Ash Stabilized Laterite as Fill Material for Low-volume Pavement. Nigerian Journal of Technology, 39 (3): 721-731.

Oke, J. A. and Osinubi, K. J. (2020). Effects of Compactive Effort on Laterite - Oil Palm Empty Fruit Bunch Ash Mixture. Covenant Journal of Engineering Technology, 4 (1): 30-48.

Omotosho, P. O. and Akinmusuru, J. O. (1992). Behaviour of Soils (Lateritic) Subjected to Multi-Cyclic Compaction. Engineering Geology, 32 (1-2): 53-58

Onyelowe, K. C.; T. Amhadi; C. Ezugwu; H. Ugwuanyi; U. Iro; I. Jideofor; E. Amanamba; D. B. U. I. Van; A. B. Salahudeen; F. Sosa; J. Aririguzo; C. Igboayaka; F. Orji; O. Ubachukwu; C. Ikpa, and B. Ugorji. (2019). Strength of Pozzolan Soil Blend in Chemically Improved Lateritic Soil for Pavement Base Material Purpose. International Journal of Low-Carbon Technologies 14(3):410-416. doi:10.1093/ijlct/ctz035.

Qian, J.; X. Shu; Q. Dong; J. Ling and B. Huang. (2015). Laboratory Characterization of Controlled Low-Strength Materials. Materials \& Design, 65(2015):806-813.

https://doi.org/10.1016/j.matdes.2014.10.012. 